\title{
Probiotic and synbiotic in broiler diet: performance and Enterobacteriaceae
}

\author{
[Probiótico e simbiótico em ração para frangos: desempenho e Enterobacteriaceae] \\ P.R.S.C. Leite ${ }^{1}$, H.B. Oliveira ${ }^{2}$, V.B.L. Souza ${ }^{2}$, F.O. Rocha ${ }^{2}$, T.H. Oliveira ${ }^{2}$ \\ ${ }^{1}$ Instituto Federal Goiano - Ceres, GO \\ ${ }^{2}$ Aluno de graduação - Instituto Federal Goiano - Ceres, GO
}

\begin{abstract}
The objective of this study was to evaluate the effects of probiotics and synbiotics on the performance and Enterobacteriaceae count of broiler chickens. A total of 640 one-day-old male broiler chicks were distributed in a completely randomized design with four treatments and eight replicates with 20 birds each. The treatments were: ration with performance enhancer (zinc bacitracin; positive control); ration without performance enhancer and probiotic/synbiotic (negative control); ration with probiotics; and ration with synbiotics. At 35 days, five birds from each treatment were euthanized and intestinal contents were harvested for determining the Enterobacteriaceae count. The performance data and average colonyforming units (CFUs) transformed as log CFU/g were subjected to analysis of variance and Tukey's test. The effects of probiotics and synbiotics were observed in the initial phase, with supplemented birds exhibiting comparable weight gain to those supplemented with bacitracin. No effect of the treatment on broiler performance was observed after 42 days. The enterobacterial count was comparable among all experimental treatments. Supplementation with probiotics and synbiotics did not compromise the performance of broilers and did not alter the Enterobacteriaceae count.
\end{abstract}

Keywords: bacitracin, Escherichia coli, microbiota

\section{RESUMO}

Objetivou-se avaliar o efeito do probiótico e do simbiótico sobre o desempenho e a contagem de Enterobacteriaceae em frangos. Foram utilizados 640 pintos de corte, machos, de um dia de idade, distribuídos em delineamento inteiramente ao acaso, com quatro tratamentos, oito repetições com 20 aves cada. Os tratamentos foram: ração com melhorador de desempenho (bacitracina de zinco) (controle positivo); ração sem melhorador de desempenho e sem probiótico/simbiótico (controle negativo); ração com probiótico e ração com simbiótico. Aos 35 dias, cinco aves por tratamento foram eutanasiadas para retirada de conteúdo intestinal e determinação de Enterobacteriaceae. As médias das unidades formadoras de colônias, transformadas em $\log / U F C / g$, e de desempenho foram submetidas à análise de variância e comparadas pelo teste Tukey. Foi observado efeito do probiótico e do simbiótico na fase inicial, sendo que aves apresentaram os mesmos resultados de ganho de peso e de peso corporal que o grupo de aves alimentado com bacitracina. Aos 42 dias, não houve efeito dos tratamentos sobre o desempenho. Aves que não receberam nenhum aditivo não apresentaram maior contagem de enterobactérias, sendo semelhantes aos demais tratamentos. A adição do probiótico e do simbiótico não compromete o desempenho dos frangos e não altera a contagem de Enterobacteriaceae.

Palavras-chave: bacitracina, Escherichia coli, microbiota

\section{INTRODUCTION}

The use of antimicrobials has provided better feed conversion and weight gain in poultry for more than 50 years. However, because of the emergence of resistant bacteria, the number of antimicrobials permitted for use in animal husbandry has become increasingly limited.

Recebido em 11 de junho de 2020

Aceito em 1 de setembro de 2020

E-mail: paulo.ricardo@ifgoiano.edu.br 
Colistin sulfate was banned in 2016, followed by a more recent prohibition of tylosin, lincomycin, and tiamulin, by the Brazilian Ministry of Agriculture.

Thus, with the decreasing number of permitted antimicrobials, it has become necessary to study alternative additives that can achieve similar results, maintain intestinal health and immune system of birds, and improve nutrient utilization without inducing bacterial resistance, particularly probiotics and prebiotics (Wang et al., 2016). Probiotics consist of one or more live microorganisms that beneficially affect the endogenous microbiota and may include species of Lactobacillus, Bifidobacterium, Enterococcus, and yeast (Al-Khalaifa et al., 2019), whereas prebiotics are defined as ingredients that are nondigestible by animals and serve as substrates for beneficial bacteria. The combination of probiotics and prebiotics yields is called synbiotics, e.g., fructooligosaccharides (FOS) combined with bifidobacterial, which exert a synergistic effect and enhance bird performance, without leaving residues in the carcass (Aziz-Mousavi et al., 2015; Beski and Al-Sardary, 2015; Reis and Vieites, 2019).

The addition of probiotics to chicken feed ameliorates feed conversion and body weight, which may be attributed to higher absorption of nutrients and improved bird performance and immunity, as reported by Royan (2018) using the probiotic species Enterococcus faecium. He et al. (2019) reported better performance and greater production of immunoglobulins in broilers fed diets containing Bacillus subtilis. Similarly, Ramlucken et al. (2020) reported that B. subtilis and Bacillus velezensis produce exogenous enzymes, improving nutrient utilization and feed conversion in supplemented animals.

Similar to probiotics, synbiotics can improve nutrient absorption because of the contained prebiotics, as stated by Aziz-Mousavi et al. (2015), who used a synbiotic combination of $E$. faecium and fructooligosaccharides in chicken feed and noted greater weight gain, better feed conversion, and higher protein consumption in supplemented birds. Cheng et al. (2017), Shokri et al. (2017), and Kridtayopas et al. (2019) also reported better bird performance on addition of synbiotics to chicken diet.
In addition, probiotics and synbiotics promote multiplication of beneficial bacteria to the detriment of pathogenic bacteria, as demonstrated by Fonseca et al. (2010) and Zhang et al. (2014). Śliżewska et al. (2020) reported higher numbers of Bifidobacterium spp. and Lactobacillus spp., and lower numbers of Clostridium spp. and Escherichia coli in the intestine of broilers supplemented with synbiotics. Kridtayopas et al. (2019), Mora et al. (2019), and Chen and Yu (2020) also reported an improvement in the population of beneficial bacteria along with pathogen control by synbiotics.

Ateya et al. (2019) observed that synbiotics combined with organic acids weakened the inflammatory response in the intestine of chickens challenged with $E$. coli, resulting in better performance, and lower mortality and bacterial elimination in the environment. In summary, replacement of performance enhancers by proand synbiotics has varying effects on the performance and intestinal microbiota of poultry. The best response depends on several factors, such as product composition, microorganism survival, dosage, and the challenge or stress conditions to which birds are exposed (Reis and Vieites, 2019; Shanmugasundaram et al., 2019; Chen and $\mathrm{Yu}, 2020)$. Therefore, the objective of this study was to determine the effects of probiotic and synbiotics on the performance and Enterobacteriaceae count of chickens challenged with reused litter and untreated water.

\section{MATERIAL AND METHODS}

The experiment was approved by the Animal Use Ethics Commission (CEUA)- IF Goiano, under protocol number 7572161018. Experiments were performed using 640 one-day-old male Cobb broiler chicks $(40.0 \pm 4.0 \mathrm{~g})$ distributed in four treatment groups, with eight replicates each and 20 birds per replicate, following a completely randomized design. The experimental diets (Table 1) were formulated according to the recommendations of Rostagno et al. (2017) based on the nutritional requirements during the different breeding phases, and consisted of prestarter ( 1 to 7 days), starter (8 to 21 days),grower (22 to 35 days), and finisher (36 to 42 days) diets.

The addition of the probiotics or synbiotics were added based on the manufacturer's recommendations, and the treatments were 
designed as follows: Treatment 1 - feed with performance enhancer (zinc bacitracin; positive control); Treatment 2 - feed without performance enhancer and probioticlsynbiotic (negative control); Treatment 3 - feed supplemented with probiotic $(150 \mathrm{~g} / \mathrm{ton}$ feed). Treatment 4 - feed supplemented with synbiotic $(100 \mathrm{~g} / \mathrm{ton}$ of feed).

The probiotics added in Treatment 3 included the following species, expressed in colony-forming units (CFU)/g: Lactobacillus plantarum $(1.26 \times$ $\left.10^{8} \mathrm{CFU} / \mathrm{g}\right)$, Lactobacillus bulgarius $\left(2.06 \times 10^{8}\right.$
CFU/g), Lactobacillus acidophilus $\left(2.06 \times 10^{8}\right.$ CFU/g), Lactobacillus rhamnosus $\left(2.06 \times 10^{8}\right.$ CFU/g), Bifidobacterium bifidum $\left(2.00 \times 10^{8}\right.$ $\mathrm{CFU} / \mathrm{g})$, Streptococcus thermophilus $\left(4.10 \times 10^{8}\right.$ $\mathrm{CFU} / \mathrm{g})$, and E. faecium $\left(6.46 \times 10^{8} \mathrm{CFU} / \mathrm{g}\right)$, whereas the added synbiotic (Treatment 4 ) was composed of anaerobic bacteria $\left(10^{4} \mathrm{CFU} / \mathrm{g}\right)$, lactic acid-producing bacteria $\left(10^{4} \mathrm{CFU} / \mathrm{g}\right)$, and mannan-oligosaccharides $\quad(370 \mathrm{~g} / \mathrm{kg})$. The bacterial species included in the synbiotic were not specified by the manufacturer.

Table 1. Percentage and calculated composition of diets for the different breeding phases

\begin{tabular}{lcccc}
\hline \multicolumn{1}{c}{ Ingredients } & Pre-Starter & Starter & Grower & Finisher \\
\hline Corn & 56.119 & 59.916 & 62.429 & 67.311 \\
Soybean meal, 45\% & 37.619 & 34.254 & 31.491 & 27.174 \\
Soybean oil & 2.165 & 2.239 & 2.926 & 2.716 \\
Bicalcium phosphate & 1.914 & 1.505 & 1.255 & 1.040 \\
Limestone & 0,816 & 0.840 & 0.809 & 0.731 \\
DL-Methionine 98\% & 0.364 & 0.300 & 0.255 & 0.239 \\
L-lysine HCL 99\% & 0.339 & 0.233 & 0.193 & 0.237 \\
Salt (NaCl) & 0.300 & 0.400 & 0.350 & 0.350 \\
L-Threonine 99\% & 0.122 & 0.071 & 0.050 & 0.052 \\
Vitamin premix ${ }^{2}$ & 0.100 & 0.100 & 0.100 & 0.100 \\
Mineral premix ${ }^{2}$ & 0.050 & 0.050 & 0.050 & 0.050 \\
Anticoccidian ${ }^{3}$ & 0.055 & 0.055 & 0.055 & ------- \\
Zinc bacitracin & 0.037 & 0.037 & 0.037 & ------ \\
\hline Total & 100.0 & 100.0 & 100.0 & 100.0 \\
\hline Nutritional composition & & & & \\
Metabolizable energy (kcal/kg) & 2.950 & 3.000 & 3.100 & 3.150 \\
Crude protein (\%) & 22.20 & 20.80 & 19.50 & 18.00 \\
Calcium (\%) & 0.920 & 0.819 & 0.732 & 0.638 \\
Available phosphorus (\%) & 0.470 & 0.391 & 0.342 & 0.298 \\
Available Lysine $(\%)$ & 1.333 & 1.174 & 1.078 & 1.01 \\
Available Methionine + Cystine $(\%)$ & 0.944 & 0.853 & 0.787 & 0.737 \\
Available Methionine (\%) & 0.647 & 0.571 & 0.519 & 0.485 \\
Available Threonine (\%) & 0.852 & 0.763 & 0.701 & 0.656 \\
\hline Vitam prix
\end{tabular}

${ }^{1}$ Vitamin premix containing: Folic acid (min) 700mg, Pantoathenic Acid (min) 8000mg, Biotin (min) 60mg, Niacin (min) 30g, Selenium (min) 400mg, Vit. A (min), 8.000.000 IU, Vit. B1 (min) 3000mg, Vit. B12 (min) $10.000 \mathrm{cg}$, Vit. B2 (min), 4,000mg, Vit. B6 (min) 2000mg, vit. D3 (min) 2.000.000 IU, Vit. E, (min) $15.000 \mathrm{IU}$, Vit. K3 (min) $2000 \mathrm{mg}$. 2 Mineral pre-mix containing: zinc, $(\min ) 125 \mathrm{~g}$ copper $(\min ) 12,6 \mathrm{~g}$. Iodine, (min) 2,.520mg. Iron (min) $105 \mathrm{~g}$. Manganese (min) 126g. ${ }^{3}$ Anticoccidian: salinomycin sodium (min) $12 \mathrm{~g}$.

Birds were challenged by reusing the same litter without treatment, cleaning pendular drinkers only once every week, and offering water without chlorine treatment. The performance of the birds was evaluated weekly and at the end of each phase. Feed consumption, weightgain, feed conversion, and final weight were measured. At 35 days of age, five birds from each treatment were euthanized by cervical dislocation and the number of bacteria (Enterobacteriaceae) in the small intestine was determined.

The intestinal contents were harvested, homogenized, and pooled to form a composite sample. Subsequently, $0.5 \mathrm{~g}$ of the sample was transferred to test tubes containing $4.5 \mathrm{~mL}$ of $0.1 \%$ sterile buffered saline, resulting in a $10^{-1}$ dilution, and successive dilutions up to $10^{-4}$ were prepared. To determine the number of enterobacteria, 
$0.1 \mathrm{~mL}$ each of the $10^{-2}$ and $10^{-4}$ dilutions was placed into duplicate Petri dishes containing MacConkey agar. The averages of the CFUs were transformed into log CFUIg and submitted, as well as the performance data, to an analysis of variance and compared pairwise using Tukey's test at $5 \%$ significance, using the statistical program $\mathrm{R}$.

\section{RESULTS AND DISCUSSION}

The diets with the addition of probiotics and synbiotics provided broilers with similar weight gain and final weight results as those fed diets containing zinc bacitracin (Table 2).

Table 2. Performance of Cobb broilers supplemented with probiotics and synbiotics from day 1 to 21

\begin{tabular}{lcccc}
\multicolumn{1}{c}{ Treatment } & Body weight gain $(\mathrm{kg})$ & Feed intake $(\mathrm{kg})$ & Feed conversion ratio & Body weight $(\mathrm{kg})$ \\
\hline Positive control & $0.966^{\mathrm{a}}$ & 1.509 & 1.499 & $1.006^{\mathrm{a}}$ \\
Negative control & $0.914^{\mathrm{b}}$ & 1.456 & 1.525 & $0.954^{\mathrm{b}}$ \\
Probiotic & $0.969^{\mathrm{a}}$ & 1.501 & 1.486 & $1.010^{\mathrm{a}}$ \\
Synbiotic & $0.963^{\mathrm{a}}$ & 1.495 & 1.490 & $1.003^{\mathrm{a}}$ \\
C.V* $(\%)$ & 3.24 & 4.07 & 3.21 & 3.11 \\
P value & 0.003 & 0.337 & 0.3897 & 0.003 \\
\hline
\end{tabular}

*coefficient of variation. Values with different superscript letters within a column are significantly different (5\%, Tukey's test).

It is thus evident that the alternative additives did not compromise the weight of broilers in the starter phase, as opposed to broilers that did not receive any additives, which presented lower body weight. This is consistent with the results of He et al. (2019), Min et al. (2016), Ramlucken et al. (2020), and Zang et al. (2014), who reported beneficial effects of probiotics and synbiotics on the performance of broilers in the starter phase. It must be noted that the imposed sanitary challenge, i.e., reusing litter without treatment, only weekly cleaning of pendular drinkers, and providing water without chlorine, affected birds in the starter phase, which represents the period when the animal immune system is still developing.

The reused litter without treatment may contain numerous microorganisms and pathogens. Roll et al. (2011) emphasized the importance of litter treatment for controlling Salmonella spp. Vieira et al. (2015) detected E. coli in reused litter samples, whereas Wang et al. (2016) identified several genera of bacteria in reused chicken litter, including Escherichia, Staphylococcus, and Corynebacterium.

Regarding water quality, it is common practice to provide chlorinated water and to clean pendular drinkers at least twice every day. Amoroso et al. (2015) reported a higher number of coliforms and E. coli in unfiltered water with possible fecal contamination. E. coli can result in poor performance of chickens, which can be prevented by supplementation with probiotic and synbiotics, as these additives weaken the inflammatory response to bacteria (Ateya et al. 2019).

However, the sanitary challenge did not impair broiler performance, which may be due to the strengthening of the immune system by the added probiotics and synbiotics, as reported by Luoma et al. (2017), Al-Khalaifa et al. (2019), and He et al. (2019). Zhang et al. (2014) challenged 7-dayold chicks with $E$. coli and reported higher immunoglobulin production in birds fed diets containing probiotics based on Clostridium butyricum, 14 days after pathogen challenge, and attributed the better performance of birds to said immunological reaction.

The better performance of birds in the starter phase may be attributed to improved nutrient utilization on supplementation with probiotics and synbiotics because some microorganisms used as probiotics, such as Bacillus spp., produce exogenous enzymes that promote degradation and more efficient use of nutrients. This was reflected in the higher feed conversion and greater weight gain of birds at 21 days of age, which was consistent with the results of He et al. (2019) and Ramlucken et al. (2020). During the entire breeding period, i.e., from day 1 to 42 (Table 3), the performance of birds fed diets without antimicrobial supplementation (Treatment 2) and with added probiotics and synbiotics (Treatments 3 and 4) was comparable to that of birds supplemented with a conventional antimicrobial (zinc bacitracin; Treatment 1). 
Table 3. Performance of Cobb broilers supplemented with probiotics and synbiotics from day 1 to 42

\begin{tabular}{lcccc}
\multicolumn{1}{c}{ Treatment } & Body weight gain $(\mathrm{kg})$ & Feed intake $(\mathrm{kg})$ & Feed conversion ratio & Body weight $(\mathrm{kg})$ \\
\hline Positive control & 2.837 & 4.747 & 1.649 & 2.877 \\
Negative control & 2.709 & 4.593 & 1.670 & 2.750 \\
Probiotic & 2.731 & 4.562 & 1.647 & 2.772 \\
Synbiotic & 2.761 & 4.669 & 1.666 & 2.801 \\
C.V (\%) & 4.25 & 6.06 & 6.64 & 4.18 \\
P value & 0.169 & 0.564 & 0.947 & 0.172 \\
\hline
\end{tabular}

This was consistent with the results of Souza et al. (2018), who did not observe greater weight gain or better feed conversion in chickens supplemented with probiotics containing $B$. subtilis, Bifidobacterium bifidum, and E. faecium for 42 days. According to these authors, the sanitary challenge (reused litter with treatment and cleaning of drinking fountains every 2 days) to which birds were subjected may not have been sufficient to verify the beneficial effects of probiotics. However, birds were exposed to a more intense sanitary challenge in the present study, in the form of reused litter without treatment and cleaning of the pendular drinkers only once per week, which resulted in lower weight and poor feed conversion after 42 days.

Mora et al. (2019) did not observe any effect of synbiotic administration via water on feed conversion and weight gain of broilers challenged with Salmonella Typhimurium and Clostridium perfringens after 42 days. The authors attributed the differences in the results of probiotic- and synbiotic supplementation to the condition of the experimental birds, species included in the probiotic, and the type of fiber contained in the prebiotic.

In general, our study presented satisfactory results for probiotics and synbiotic supplementation. During both the starter phase and the total breeding period, the performance of broilers supplemented with the alternative additives was comparable to that of birds that received zinc bacitracin, which is a traditional antimicrobial for poultry. It should be noted that when considering the performance of birds supplemented with probiotics or synbiotics, several factors, such as probiotic composition, dosage, route of administration, and type and viability of microorganisms in the gastrointestinal tract, must be taken into account in addition to the imposed health challenge, as emphasized by Mora et al. (2019), Reis and Vieites (2019), and Shanmugasundaram et al. (2019).
The treatments did not affect the total Enterobacteriaceae count in the small intestine (Table 4). A higher Enterobacteriaceae count was expected in birds that did not receive any additives in the feed because both zinc bacitracin and probiotics can decrease the population of enterobacteria, coliforms, and $E$. coli in the intestine, as reported by Engberg et al. (2000), Fonseca et al. (2010), Boostani et al. (2013), and Carrasco et al. (2018).

In addition, birds subjected to the sanitary challenge likely ingested a greater amount of coliforms, because of the poor quality of the water provided (without chlorine and containing organic matter and/or excreta because of unclean drinkers). According to Amoroso et al. (2015), untreated and poor-quality water contains a higher number of coliforms, including E. coli.

Table 4. Enterobacteriaceae count in the small intestine of Cobb broilers supplemented with probiotics and synbiotics for 35 days

\begin{tabular}{lcc}
\hline Treatment & $\begin{array}{c}\text { Second } \\
\text { dilution } \\
\log (\mathrm{CFU} / \mathrm{g})\end{array}$ & $\begin{array}{c}\text { Fourth } \\
\text { dilution } \\
\log (\mathrm{CFU} / \mathrm{g})\end{array}$ \\
\hline Positive control & 4.626 & 5.777 \\
Negative control & 3.742 & 5.595 \\
Probiotic & 4.047 & 5.369 \\
Synbiotic & 4.260 & 5.675 \\
C.V. (\%) & 16.96 & 12.09 \\
P value & 0.284 & 0.805 \\
\hline
\end{tabular}

However, the additives did not alter the Enterobacteriaceae population, which was consistent with the observations of Sherief et al. (2012), who did not report any effect of probiotics and synbiotics on the total count of coliforms, Escherichia coli, or aerobic bacteria. Our results were also in agreement with those of Torok et al. (2011), who did not observe any change in the enterobacterial population on supplementation with zinc bacitracin. Moreover, Mora et al. (2019) and Śliżewska et al. (2020) did not report any 
change in the Enterobacteriaceae count in the intestine of broilers supplemented with synbiotics. Conversely, Dibaji et al. (2014) reported a reduction in the $E$. coli and total coliform count in the cecum of broilers supplemented with synbiotics (E. faecium and fructooligosaccharides). Ateya et al. (2019) noted a reduction in the lipopolysaccharide receptor (TLR4), associated with the inflammatory process, in the intestine of chickens supplemented with probiotic and synbiotics, indicating a lower inflammatory response on challenge with $E$. coli.

In contrast, the use of probiotics or synbiotics has been reported to alter the microbiota in terms of the numbers of beneficial gram-positive bacteria, such as Lactobacillus sp. and Bacillus sp., which were shown to multiply and produce acids, thus lowering the intestinal $\mathrm{pH}$ and likely controlling pathogenic microorganisms (Sherief et al., 2012). Chen and Yu (2020) analyzed the fecal microbiota of chickens supplemented with Bacillus licheniformis and noted a greater amount of Lactobacillus on probiotic addition to feed $(3 \mathrm{~g} / \mathrm{kg})$, demonstrating a positive correlation between the additive and higher body weight of birds.

Synbiotic supplementation significantly increased the lactic acid level and total short chain fatty acids (i.e., acetic, propionic, valeric, butyric, and formic acids). Short chain fatty acids play important roles in $\mathrm{pH}$ regulation, increase calcium, iron, and magnesium absorption, and positively affect hepatic metabolism of glucose and proteins. These fatty acids are very important in the maintenance of the structure, function, and integrity of the intestine for inhibiting Salmonella, E. coli, and Campylobacter (Śliżewska et al., 2020).

According to He et al. (2019) and Ramlucken et al. (2020), the probiotic composition is important because certain bacteria, such as $B$. subtilis, $B$. velezensis, and $B$. licheniformis, are aerobic and provide a suitable environment for lactobacilli and bifidobacteria under anaerobic conditions, which subsequently produce acids and lower the intestinal $\mathrm{pH}$, preventing the growth of pathogenic microorganisms. Bacillus, Lactobacillus, and Bifidobacterium aregram-positivegenera and were not investigated in the present study because the culture medium used, i.e., MacConkey agar, specifically selects gram-negative bacteria.
The results of the present study and those of other studies on the effect of additives on enteric microbiota evidence the microorganismal diversity and indicate that changes in the enterobacterial population depend on multiple factors. Thus, the handling of litter, food offered, type and composition of the probiotics/synbiotics, method of enterobacterial determination, included microorganisms, and intestinal location for the Enterobacteriaceae count must be considered. Furthermore, it is important to test new probiotic strains, including some fungal species, for potential poultry applications.

\section{CONCLUSION}

The addition of probiotics and synbiotics did not compromise the performance of broilers and did not alter the intestinal Enterobacteriaceae count.

\section{ACKNOWLEDGMENT}

The authors thank Instituto Federal Goiano for its financial support.

\section{REFERENCES}

AL-KHALAIFA, H.; AL-NASSER, A.; ALSURAYEE, T. et al. Effect of dietary probiotics and prebiotics on the performance of broiler chickens. Poult. Sci., v.98, p.4465-4479, 2019.

AMOROSO, L.; BARALDI-ARTONI, S.M.; SOARES, N.M. et al. Influência da qualidade microbiológica da água de dessedentação na morfologia intestinal de frangos de corte. Pesqui. Vet. Bras., v.35, p.80-88, 2015.

ATEYA, A.I.; ARAFAT, N.; SALEH, R.M. et al Intestinalgene expressions in broiler chickens infected with Escherichia coli and dietary supplemented with probiotic, acidifier and synbiotic. Vet. Res., v.43, p.131-142, 2019.

AZIZ-MOUSAVI, S.M.A.; SEIDAVI, A.; DADASHBEIKI, M. et al. Effect of a synbiotic (Biomin $® I M B O)$ ongrowth performance traits of broiler chickens. Eur. Poult. Sci., v.79, 2015.

BESKI, S.S.M.; AL-SARDARY, S.Y.T. Effects of dietary supplementation of probiotic and synbiotic on broiler chickens hematology and intestinal integrity. Int. J. Poult. Sci., v.14, p.3136, 2015. 
BOOSTANI, A.; MAHMOODIAN FARD, H.R.; ASHAYERIZADEH, A. et al.growth Performance, carcass yield and intestinal microflora populations of broilers fed diets containing thepax and yogurt. Braz. J. Poult. Sci., v.15, p.1-6, 2013.

CARRASCO, J.M.D.; REDONDO, E.A.; VISO, N.D.P. et al. Tannins and bacitracin differentially modulategut microbiota of broiler chickens. Bio Res. Int., v.2018, p.1-12, 2018.

CHEN, Y.C.; YU, Y.H. Bacillus licheniformisfermented products improvegrowth performance and the fecal microbiota community in broilers. Poult. Sci., v.99, p.1432-1443, 2020.

CHENG, Y.; CHEN, Y.; LI, X. et al. Effects of synbiotic supplementation ongrowth performance, carcass characteristics, meat quality and muscular antioxidant capacity and mineral contents in broilers. J. Sci. Food Agric., v.97, p.3699-3705, 2017.

DIBAJI, S.M.; SEIDAVI, A.; ASADPOUR, L. et al. Effect of a synbiotic on the intestinal microflora of chickens. J. Appl. Poult. Res., v.23, p.1-6, 2014.

ENGBERG, R.M.; HEDEMAN, M.S.; LESER, T.D. et al. Effect of zinc bacitracin and salinomycin on intestinal microflora and performance of broilers. Poult. Sci., v.79, p.13111319, 2000.

FONSECA, B.B.; BELETTI, M.E.; SILVA, M.S. et al. Microbiota of the cecum, ileum morphometry, $\mathrm{pH}$ of the crop and performance of broiler chickens supplemented with probiotics. Rev. Bras. Zootec., v.39, p.1756-1760, 2010.

HE, T.; LONG, S.; MAHFUZ, S. et al. Efects of probiotics as antibiotics substitutes ongrowth performance, serum biochemical parameters, intestinal morphology, and barrier function of broilers. Animal, v.9, p.2-10, 2019.

KRIDTAYOPAS， C.; RAKANGTONG， C.; BUNCHASAK, C. et al. Effect of prebiotic and synbiotic supplementation in diet ongrowth performance, small intestinal morphology, stress, and bacterial population under high stocking density condition of broiler chickens. Poult. Sci., v.98, p.4595-4605,2019.
LUOMA, A..; MARKAZI, A.; SHANMUGASUNDARAM, R. et al. Effect of synbiotic supplementation on layer production and cecal Salmonella load during a Salmonella challenge. Poult. Sci., v.96, p.4208-4216, 2017.

MIN, Y.N.; YANG, H.L.; XU, Y.X. et al. Effects of dietary supplementation of synbiotics ongrowth performance, intestinal morphology, sIgA content and antioxidant capacities of broilers. J. Anim. Physiol. Anim. Nutr., v.100, p.1073-1080, 2016.

MORA, Z.V.; NUÑO, K.; VÁZQUEZPAULINO, O. et al. Effect of a synbiotic mix on intestinal structural changes, and Salmonella Typhimurium and Clostridium perfringens colonization in broiler chickens. Animal, v.9, p.777, 2019.

RAMLUCKEN, U.; RAMCHURAN, S.O.; MOONSAMY, G. et al. A novel Bacillus based multi-strain probiotic improvesgrowth performance and intestinal properties of Clostridium perfringens challenged broilers. Poult. Sci., v.99, p.4331-341, 2020.

REIS, T.L.; VIEITES, F.M. Antibiótico, prebiótico, probiótico e simbiótico em rações de frangos de corte egalinhas poedeiras. Ciênc. Anim. Bras., v.29, p.133-147, 2019.

ROLL, V.F.B.; PRA, M.A.D.; ROLL, A.P. Research on Salmonella in broiler litter reused for up to 14 consecutive flocks. Poult. Sci., v.90, p.2257-2262, 2011.

ROSTAGNO, H.S.; ALBINO, L.F.T.; HANNAS, M.I. et al. Tabelas brasileiras para aves e suínos: composição de alimentos e exigências nutricionais. 4.ed. Viçosa: UFV, 2017.488p.

ROYAN, M. The use of enterococci as probiotics in poultry. Iran. J. Appl. Anim. Sci., v.8, p.559$565,2018$.

SHANMUGASUNDARAM, R.; MORTADA, M.; MURUGESAN, G.R. et al. In vitro characterization and analysis of probiotic species in the chicken intestine by real-time polymerase chain reaction. Poult. Sci., v.98, p.5840-5846, 2019. 
SHERIEF, A.M.; ABD-ALLAH, S.M.S.; HASSANEIN, K.M.A. The effects of prebiotic, probiotic and synbiotic supplementation on intestinal microbial ecology and histomorphology of broiler chickens. Int. J. Agro Vet. Med. Sci., v.6, p.277-289, 2012.

SHOKRI, A.N.; GHASEMI, H.A.; TAHERPOUR, K. Evaluation of Aloe vera and synbiotic as antibiotic growth promoter substitutions on performance, gut morphology, immune responses and blood constitutes of broiler chickens. Anim. Sci. J., v.88, p.306-313, 2017.

ŚLIŻEWSKA, K.; MARKOWIAK-KOPEĆ1, P.; ŻBIKOWSKI, ARTUR. et al. The effect of synbiotic preparations on the intestinal microbiota and her metabolism in broiler chickens. Sci. Rep., v.10, p.1-13, 2020.

SOUZA, L.F.A.; ARAÚJO, D.N.; STEFANI, L.M.A. et al. Probiotics on performance, intestinal morphology and carcass characteristics of broiler chickens raised with lower or higher environmental challenge. Aust. J. Vet. Sci., v.50, p.35-41, 2018.
TOROK, V.A.; ALLISON, G.E.; PERCY, N.J. et al. Influence of antimicrobial feed additives on broiler commensal posthatchgut microbiota development and performance. Appl. Environ. Microbiol., v.77, p.3380-3390, 2011.

VIEIRA, M.F.A.; TINOCO, I.F.F.; SANTOS, B.M. et al. Sanitary quality of broiler litter reused. Eng. Agric., v.35, p.800-807, 2015.

WANG, L.; LILBURN, M.; ZHONGTANA. Y. Intestinal microbiota of broiler chickens as affected by litter management regimens. Front. Microbiol., v.7, p.593, 2016.

WANG, X.; FARNELL, Y.Z.; PEEBLES, E.D. et al. Effects of prebiotics, probiotics, and their combination on growth performance, small intestine morphology, and resident Lactobacillus of male broilers. Poult. Sci., v.95, p.1332-1340, 2016.

ZHANG, L.; CAO, G.T.; ZENG, X.F. et al. Effects of Clostridium butyricum ongrowth performance, immune function, and cecal microflora in broiler chickens challenged with Escherichia coli K88. Poult. Sci., v.93, p.46-53, 2014. 